\title{
Production and characterization of monoclonal antibodies against small hapten-ciprofloxacin
}

\author{
Yousheng Jiang, Xuanyun Huang, Kun Hu, Wenjuan Yu, Xianle Yang* and Liqun Lv \\ College of Fisheries and Life Science, Shanghai Ocean University, Shanghai 201306, P. R. China.
}

Accepted 23 September, 2011

\begin{abstract}
High affinity and specificity monoclonal antibody against small hapten-ciprofloxaicn (CPFX) was produced and was used for rapid CPFX immunoassay in food stuffs of animal origin. Firstly, two kinds of antigens for CPFX were made using carrier proteins, bovine serum albumin (BSA) and ovalbumin (OVA), by a modified carbodiimide method and then the hapten-protein conjugates were characterized by ultraviolet spectrophotometry to detect hapten density before being used for the immunization and detection purposes. The production of monoclonal antibodies (Mabs) was sought following the generation of appropriate CPFX-BSA conjugate. Spleen cells from Balb/c mice immunized with CPFXBSA conjugate were fused with SP2/0 myeloma cells, and hybridomas secreting antibodies against CPFX were selected and cloned. One Mab against CPFX was produced and the average affinity of the Mab was $2.88 \times 10^{9} \mathrm{~L} / \mathrm{mol}$. The number of the hybridoma chromosome was 90 to 105 . Except for enrofloxacin, the Mab had not any cross-reactivity with other fluoroquinolones. In the optimized ELISA, the Mab gave a $50 \%$ inhibition of $7.77 \mathrm{ng} / \mathrm{ml}$ with a detection limit of $1.56 \mathrm{ng} / \mathrm{ml}$.
\end{abstract}

Key words: Ciprofloxacin, hapten, antibody, immunoassay.

\section{INTRODUCTION}

Ciprofloxacin (CPFX) which was introduced in 1987 (Barry and Fuchs, 1991) is one of the third generation members of synthetic fluoroquinolone group. When compared with the developed fluorine-containing pyridinecarboxylic acid derivatives, CPFX has activity about four times greater against almost all of Gramnegative bacteria (Van Caekenberghe and Pattyn, 1984). The primary mechanism of CPFX activation is the inhibition of DNA gyrase and topoisomerase IV that control DNA topology and are vital for bacterial replication (Higgins et al., 2004). Due to its broad antibiotic activity, CPFX was widely used in the veterinary therapeutic treatment of several animal species (Margarita et al., 2002). However, the CPFX residues in food chain can cause a potential risk in human through the emergence of drugresistant bacteria (Zhou et al., 2008). Thus, the maximum

*Corresponding author. E-mail: xlyang@shou.edu.cn, ysjiang@shou.edu.cn. Tel: +86-21-61900453. Fax: +86-2161900453.

Abbreviations: CPFX, Ciprofloxaicn; BSA, bovine serum albumin; OVA, ovalbumin; Mabs, monoclonal antibodies. residues limits (MRLs) $30 \mu \mathrm{g} / \mathrm{kg}$ of CPFX and enrofloxacin in food stuffs of animal origin were established in European Union (Hammer and Heeschen, 1995).

At present, many chemical analytical techniques have been established for analyzing CPFX in samples, this include spectrophotometry (Nagarall et al., 2002), fluorimetry (Veiopoulou et al., 1997), high-performance liquid chromatography (Ramos et al., 2003) and capillary electrophoresis (Hernandez et al., 2000). However, they all have some limitations in term of time-consuming and require extensive sample cleanup (Ross and Larry, 2001). Antibody-antigen reaction was used to analyze chloramphenicol (Robert, 1996), tetrodotoxin (Raybould and Inouye, 1992) and enrofloxacin (Watanabe et al., 2002). It is advantageous, in that it is cheaper in cost and involves a less operation step which make it particularly useful in routine work (Nuria et al., 2007). When compared with other methods for CPFX detection, fewer studies about immunoassays have been made and this was mainly due to lack of specific and sensitive monoclonal antibody against CPFX which can support rapid CPFX immunoassay. In this study, we prepared specific monoclonal antibodies against CPFX and established a ci-ELISA method for CPFX detection. 


\section{MATERIALS AND METHODS}

Ciprofloxacin, enrofloxacin, ofloxacin, pefloxacin, norfloxacin and sarafloxacin were purchased from Zhejiang Guobang pharmaceutical Co. Ltd. Bovine serum albumin (BSA), ovalbumin (OVA), tetramethylbenzidine (TMB) and peroxidase horseradish (HRP) were obtained from Dingguo biotechnology Co. Ltd. 1-Ethyl3carbodiimide methiodide (EDC, purity $\geq 99.3 \%$ ) was obtained from Shanghai Yanchang biochemical technology Co. Ltd. RPMI 1640, HAT, polyethylene glycol-400 (PEG) and calf serum clarified were obtained from Sigma Chemical Co. Ltd. Myeloma cells SP2/0 were conserved by our laboratory. Balb/c mice were gotten from the Second Military Medical University. Chemical reagents such as $\mathrm{NaCl}, \mathrm{KCl}$ and $\mathrm{K}_{2} \mathrm{HPO}_{4}$ were from Shanghai Guoyao Chemical Reagent Co. Ltd.

\section{Preparation of CPFX-protein conjugates}

The conjugate of CPFX-BSA was synthesized by a modified carbodiimide method. $1 \mathrm{ml}$ of CPFX $(20 \mathrm{mg} / \mathrm{ml}$ in $0.01 \mathrm{M} \mathrm{PBS}, \mathrm{pH}$ 5.0) was mixed with $1 \mathrm{ml}$ of $\mathrm{BSA}(8 \mathrm{mg} / \mathrm{ml}$ in $0.01 \mathrm{M}$ PBS, $\mathrm{pH} 5.0$ ) and $1 \mathrm{ml}$ of EDC $(240 \mathrm{mg} / \mathrm{ml}$ in $0.01 \mathrm{M}$ PBS, pH 5.0). Then $1 \mathrm{ml}$ of PBS $(0.01 \mathrm{M}, \mathrm{pH} 5.0)$ was added and the reaction was carried out in the buffer and incubated at $28^{\circ} \mathrm{C}$ for $2 \mathrm{~h}$. The mixture was dialyzed for 2 days in PBS ( $\mathrm{pH} 5.0$ ), and the dialyzing buffer was changed every day. After freeze-drying, the conjugate CPFX-BSA was obtained and stored at $-20^{\circ} \mathrm{C}$. The same method was used to prepare CPFX-OVA conjugate.

\section{Analysis of conjugates by ultraviolet spectrophotometry}

The conjugates were diluted in PBS and were scanned by thermo spectronic ultraviolet spectrophotometer, and the range of scanning wavelength was from 250 to $350 \mathrm{~nm}$. Scanning step of the obtained spectrograms was $1 \mathrm{~nm}$ at scanning speed of $1 \mathrm{~nm} / \mathrm{s}^{-1}$.

\section{Production of monoclonal antibodies}

$\mathrm{Balb} / \mathrm{c}$ mice of about 4 weeks old were injected with CPFX-BSA. A mixture of CPFX-BSA conjugate $(2 \mathrm{mg} / \mathrm{ml}, 0.1 \mathrm{ml})$ and Freunds complete adjuvant $(0.1 \mathrm{ml})$ was injected into mice intraperitoneally at the first time. The next week, a similar injection was administered using Freund's incomplete adjuvant and two booster injections were given by tail vein at 1 week intervals. Three days after the last injection, the mice were sacrificed for fusion. Spleen cells obtained from the final immunized mouse were fused with SP2/0 myeloma cells using polyethylene glycol. An indirect ELISA assay was used to screen hybridomas secreted CPFX positive antibodies. Selected hybridomas were subsequently cloned three or more times by limiting dilution, and one clone stable in culture was eventually chosen for further study. Hybridomas ( 1 to $5 \times 10^{6}$ cells) were injected into Balb/c mice ( 7 weeks old) through abdomens after liquid olefin injection for 7 days. The ascites can be obtained through the needle of a $20 \mathrm{ml}$ injector about seven days later. The Mab was purified using Protein G Sepharose 4 Fast Flow.

\section{Indirect ELISA}

CPFX-OVA $(1.6 \mu \mathrm{g} / \mathrm{ml})$ were coated into a 96-well microplate $(100$ $\mu \mathrm{l}$ per well) for $1 \mathrm{~h}$ at $37^{\circ} \mathrm{C}$. After three washes with PBST $(0.5 \%$ tween), the wells were blocked with $1 \%$ BSA in PBS overnight at $4^{\circ} \mathrm{C}$ and washed with PBST. Then the Mab $(100 \mu \mathrm{l}$ per well) were added for $1 \mathrm{~h}$ at $37^{\circ} \mathrm{C}$. Some wells in the 96-well plate were incubated with PBS as negative control and block control. After washing with PBST, the plate was incubated in the horseradish peroxidase conjugated goat anti-mouse serum (1:6000) for $0.5 \mathrm{~h}$ at $37^{\circ} \mathrm{C}$ and washed with PBST. The horseradish peroxidase reaction was developed in a substrate solution of $\mathrm{TMB} / \mathrm{H}_{2} \mathrm{O}_{2}(100 \mu \mathrm{l}$ per well) for $10 \mathrm{~min}$, then the reaction was stopped by the addition of $2 \mathrm{M}$ $\mathrm{H}_{2} \mathrm{SO}_{4}(50 \mu \mathrm{l}$ per well) and the absorbance values were measured at $450 \mathrm{~nm}$ with the precise microplate reader. All experiments were made in triplicate.

\section{Identify of hybridoma chromosome}

Hybridoma chromosome was identified by the colchicines inhibition method. The number of the chromosome was counted and the photos were taken by an Olympus microscope.

\section{Characterization of antibody}

Subclass of antibody was determined by Invitrogen's Mouse MonoAb ID Kit (HRP). Mab affinity was measured by the method of a noncompetitive enzyme immunoassay according to Beatty et al. (1983). CPFX-OVA conjugates with the concentration of $200 \mathrm{ng} / \mathrm{ml}$, $100 \mathrm{ng} / \mathrm{ml}, 50 \mathrm{ng} / \mathrm{ml}$ and $25 \mathrm{ng} / \mathrm{ml}$ was coated in a 96-well microplate $\left(100 \mu \mathrm{l}\right.$ per well) for $1 \mathrm{~h}$ at $37^{\circ} \mathrm{C}$. The subsequent steps were made as described in indirect ELISA.

A ci-ELISA was used to determine the sensitivity and specificity of Mab. CPFX-OVA conjugates with the concentration of $100 \mathrm{ng} / \mathrm{ml}$ was coated into a 96-well microplate, $50 \mu \mathrm{l}$ of Mab (1:16000) were added to each well and $50 \mu \mathrm{l}$ CPFX of different concentrations $(50$, $25,12.5,6.25,3.125,1.5625 \mathrm{ng} / \mathrm{ml}$ ) were further added. The subsequent steps were the same as described in indirect ELISA. To assess the cross-reactivity of the Mab, tests were made using enrofloxacin, ofloxacin, pefloxacin, norfloxacin and sarafloxacin.

\section{Samples preparation}

Minced samples $(5 \mathrm{~g})$ were spiked with ciprofloxacin at concentrations of 10,50 or $100 \mathrm{ng} / \mathrm{ml}$. The spiked samples were homogenized with $10 \mathrm{ml}$ ethyl acetate, vortexed for $10 \mathrm{~min}$ and centrifuged at $600 \mathrm{~g}$ for $10 \mathrm{~min}$. The supernatants were added directly to the microtiter plates and analyzed by ci-ELISA.

\section{RESULTS}

\section{Quantitative analysis of molecule conjugate ratio}

The result of UV scanning spectrums is shown in Figure 1. The maximum absorption peaks of BSA, CPFX and CPFX-BSA conjugate were at 279,270 and $274 \mathrm{~nm}$, respectively. The maximum absorption peak of CPFXBSA was different from BSA and CPFX, which indicated the success of synthesis. The successful coupling reaction between CPFX and BSA could be speculated according to the methods of Yang et al. (1998), and the molecular conjugate ratio of CPFX to BSA was 30 . CPFX-OVA was also analyzed by the UV scanning spectrums method and was found that the molecular conjugate ratio of CPFX to OVA was 12, so CPFX-OVA could be used in ELISA assay.

\section{Chromosome identification of hybridomas}

The average chromosome numbers of SP2/0 and spleen 


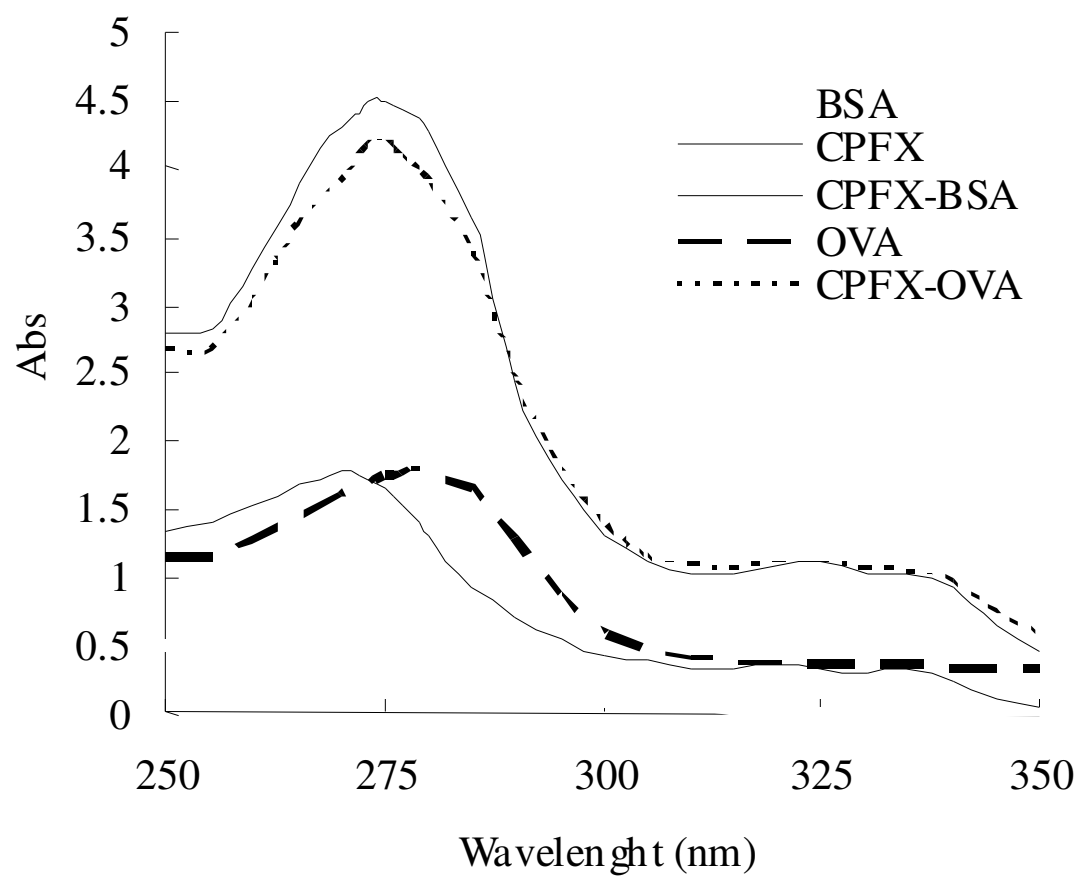

Figure 1. The ultraviolet absorb spectral curve of BSA, OVA, CPFX-BSA and CPFXOVA.

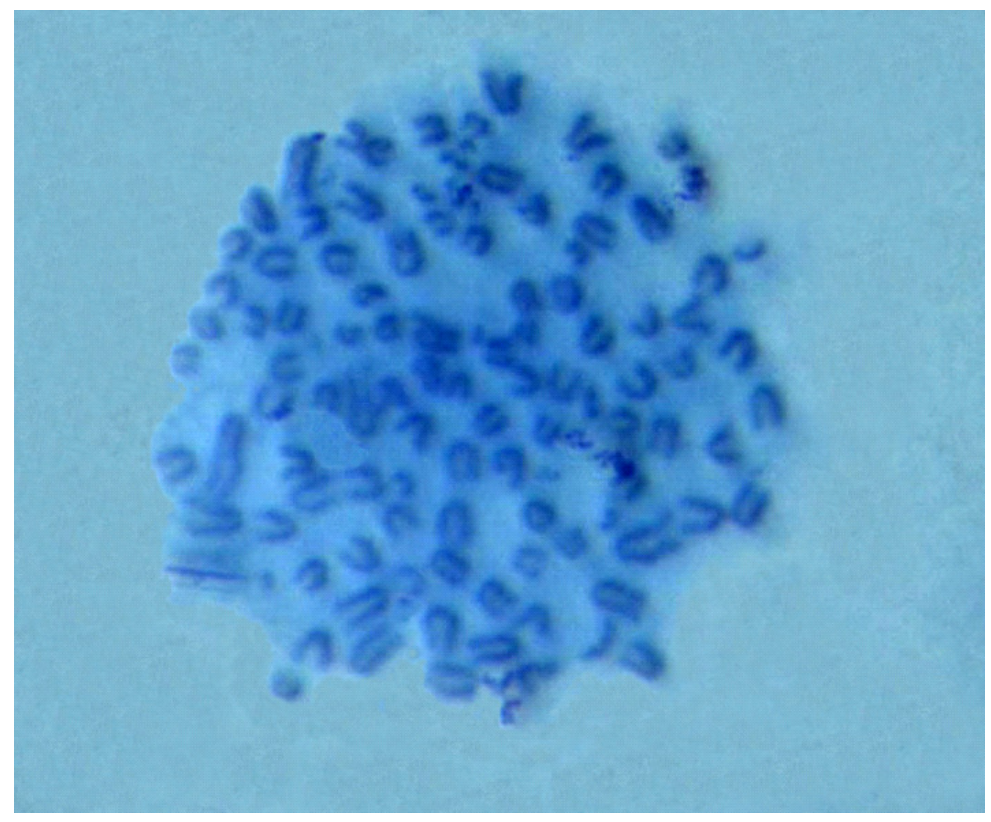

Figure 2. The chromosome of hybridoma by the colchicines inhibition method.

cells were 62 to 70 and 38 to 40 , respectively. The chromosome number of hybridomas which secreted Mab (4F5) against CPFX were 90 to 105 (Figure 2), indicating the chromosome of hybridomas were from SP2/0 and spleen cells.

\section{The characterization of Mab}

The antibody (4F5) was $\operatorname{lgG}_{2 a}$ with $\mathrm{K}$ light chain and the average affinity of $4 \mathrm{~F} 5$ was $2.88 \times 10^{9} \mathrm{~L} / \mathrm{mol}$ (Figure 3 ). Representative ci-ELISA curves for CPFX, obtained using 


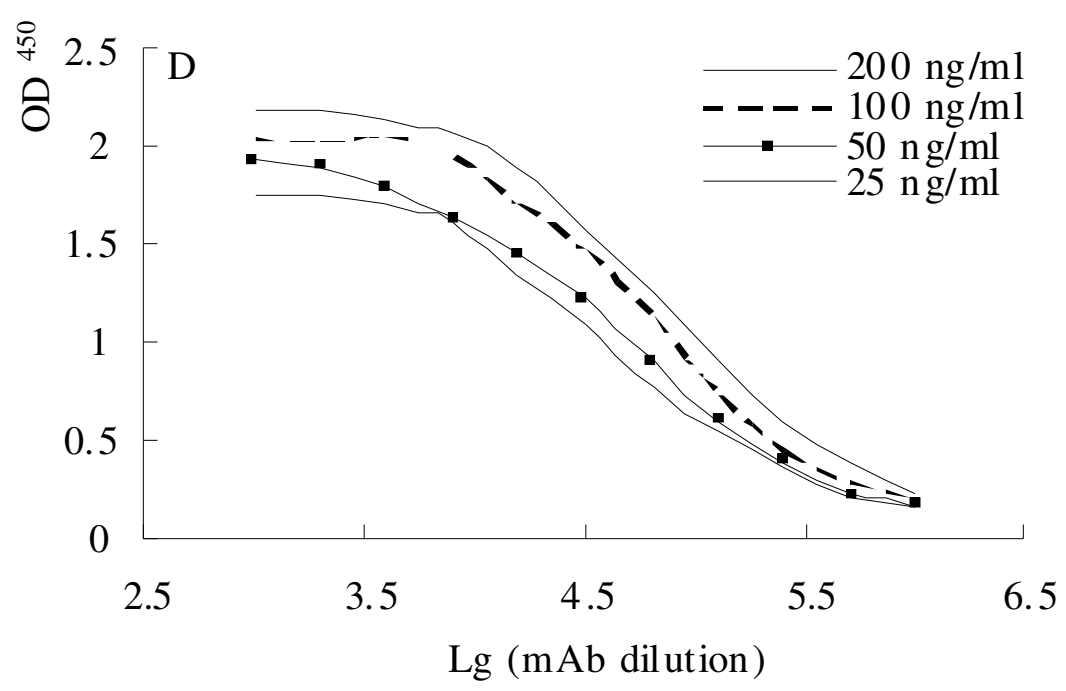

Figure 3. Measurement of Mab affinity by non-competitive ELISA. The affinity of Mab was caculated by the equation as follow: $K_{a}=(n-1) / 2 n([A b '] t-[A b] t) . n=$ $\left[\mathrm{Ag}^{\prime}\right] \mathrm{t} /[\mathrm{Ag}]_{\mathrm{t}}$. $\left[\mathrm{Ag}^{\prime}\right]_{\mathrm{t}}$ and $[\mathrm{Ag}]_{\mathrm{t}}$ were different concentration of coated antigen. $\left[A b^{\prime}\right] t$ and $[A b] t$ were the concentration of monoclonal antibody at $50 \% \mathrm{OD}_{\max }$ which was corresponding to the different coated antigen concentrations.

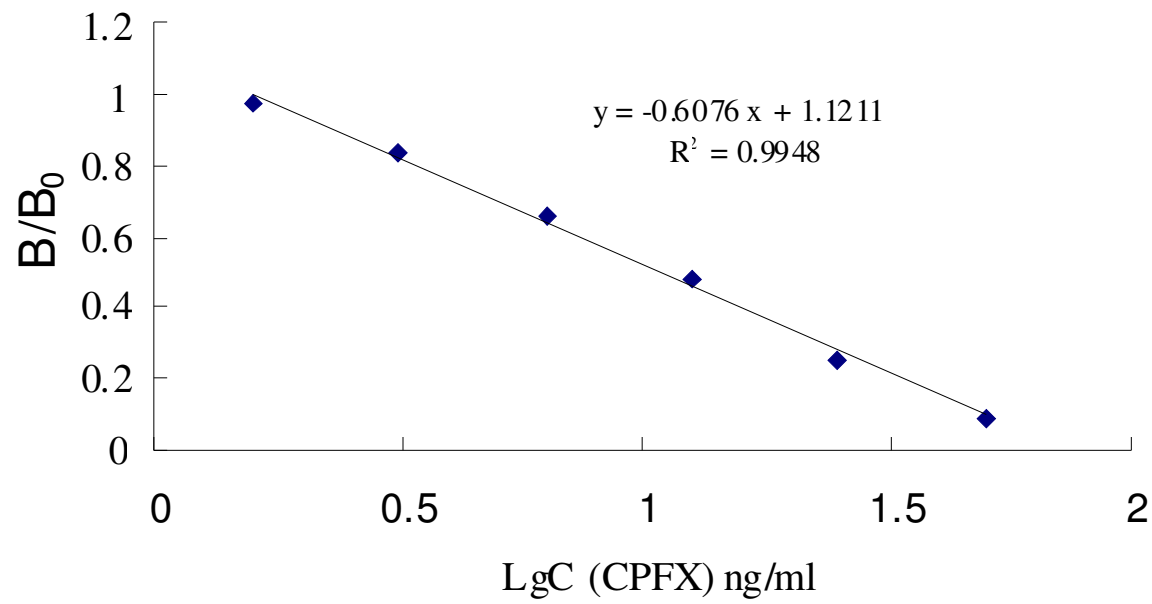

Figure 4. Standard curve of competitive direct ELISA for CPFX. Standard curves were prepared by plotting logarithm of CPFX concentration versus percent binding, which is calculated by the absorbance in the absence $\left(B_{0}\right)$ and presence $(B)$ of CPFX in standard. In the range of 1.56 to $50 \mathrm{ng} / \mathrm{ml}$, the CPFX concentration showed the good linear relationship with $\mathrm{B} / \mathrm{B}_{0}$.

monoclonal antibody are shown in Figure 4. The Mab exhibited a high sensitivity to CPFX with an $\mathrm{IC}_{50}$ value of $7.77 \mathrm{ng} / \mathrm{ml}$ and a detection limit of $1.56 \mathrm{ng} / \mathrm{ml}$. The Mab 4F5 had cross-reactivity with enrofloxacin (Table 1).

\section{Detection of ciprofloxacin in various matrices}

For used in the ELISA performance evaluation, three matrices were chosen. The recoveries are shown in Table
2. The recoveries in chicken muscle ranged from $95 \%$ to $122 \%$, recoveries in chicken liver ranged from $98 \%$ to $115 \%$ and recoveries in aqua-production ranged from $80 \%$ to $95 \%$.

\section{DISCUSSION}

The CPFX is a small-molecular hapten ( $\mathrm{MW}<1000$ ), which alone is not immunogenic, unless it is coupled with 
Table 1. Cross-reactivity of monoclonal antibody against other drugs.

\begin{tabular}{lcc}
\hline Parameter & $\mathbf{I C}_{\mathbf{5 0}}(\mathbf{n g} / \mathbf{m l})$ & CR $(\%)$ \\
\hline Ciprofloxacin & 7.77 & 100 \\
Enrofloxacin & 8.18 & 95 \\
Ofloxacin & $>100000$ & $<0.01$ \\
Pefloxacin & $>100000$ & $<0.01$ \\
Norfloxacin & $>100000$ & $<0.01$ \\
Sarafloxacin & $>100000$ & $<0.01$ \\
\hline
\end{tabular}

Table 2. Recovery of ciprofloxacin from muscle, liver, aqua-production ( $n=10)$.

\begin{tabular}{lccc}
\hline Sample & Spiked lever $(\mathbf{n g} / \mathbf{m l})$ & Recovery $(\%)$ & CV $(\%)$ \\
\hline \multirow{3}{*}{ Chicken Muscle } & 10 & $85.8 \pm 8.16$ & 9.51 \\
& 50 & $88.8 \pm 7.04$ & 7.92 \\
& 100 & $83.3 \pm 11.1$ & 13.3 \\
Chicken Liver & 10 & & \\
& 50 & $82.8 \pm 8.68$ & 10.4 \\
& 100 & $92.2 \pm 8.14$ & 9.56 \\
Aqua-production & 10 & & 9.44 \\
& 50 & $81.8 \pm 5.71$ & \\
& 100 & $81.2 \pm 9.72$ & 6.98 \\
& & $89.7 \pm 12.3$ & 12.0 \\
\hline
\end{tabular}

some macromolecules such as proteins (Singh et al., 2004). BSA was chosen as a carrier protein because it contained various amino residues on the surface and is easy to form a soluble conjugate compared with other carrier proteins. Moreover, the hapten-protein conjugate with high efficiency and this is important to the immunological analysis (Steffensa et al., 2002). It is assumed that high antibody titers and moderate antibody affinities are usually obtained with hapten density of 15 to 30 molecules per carrier protein (Singh et al., 2004). The coupling ratio of CPFX-BSA in this paper $(30: 1)$ was higher than CPFX-OVA (12:1), so CPFX-BSA can be used as immunogen.

Several synthesis methods of hapten with carrier protein were reported, such as mixed anhydride, carbodiimide method and glutaraldehyde method. However, few researches were reported about the conjugate of CPFX-protein by carbodiimide method which does not add the N-Hydroxysuccinimide. The production of monoclonal antibody also indirectly confirmed that the method of conjugating CPFX with carrier protein was successful. In ELISA assay, the conjugate CPFX-OVA were used as coating antigen to avoid the binding of Mabs with carrier protein BSA. The cross reactivity with other fluoroquinolones (FQs) of the Mabs was examined and the result showed that three Mabs had strong cross reactivity with other FQs in the four Mabs produced. One of the Mabs (4F5) against CPFX had cross-reactivity only with enrofloxacin, so the Mab (4F5) was chosen for further research. Our result shows that the Mab (4F5) had high cross reactivity with enroflxoacin. This corresponded to the work of Wang et al. (2007), who prepared monoclonal antibody against CPFX which also had high cross-reactivity with enroflxoacin. Duan and Yuan, (2001) prepared polyclonal antibodies against CPFX and the antibody exhibited a higher cross-reactivity to enroflxoacin $(70 \%)$. This may be that the structure of CPFX and enrofloxacin was similar. Both CPFX and enrofloxacin had cyclopropyl group at position 1 in ring and the lack of an ethyl group on the piperazinyl ring was not detrimental to antibody binding.

Affinity is another important parameter of Mab, it is generally believed that affinity $10^{9}$ to $10^{12} \mathrm{~L} / \mathrm{mol}$ is adapted to immunodetection. The affinity of $4 \mathrm{~F} 5$ in this paper is $2.88 \times 10^{9} \mathrm{~L} / \mathrm{mol}$ and the $\mathrm{IC}_{50}$ is $9.83 \mathrm{ng} / \mathrm{ml}$, so it could be used for CPFX analyzing. An indirect ELISA for CPFX was reported (Duan and Yuan, 2001) and it was observed that the $\mathrm{IC}_{50}$ was $50 \mathrm{ng} / \mathrm{ml}$, but the antibody was cross-reactive with enrofloxacin and norfloxacin.

In conclusion, we prepared a sensitive, specific monoclonal antibody against CPFX and it is useful for analyzing CPFX residues in the edible tissues of animals 
used as food through ci-ELISA.

\section{ACKNOWLEDGEMENTS}

\section{This research was supported by Science and Technology of Shanghai Agriculture Committee (granted 6660106477) and key projects in the National Science and Technology Pillar Program during the eleventh five- year plan period (2006BAD03B04).}

\section{REFERENCES}

Barry AL, Fuchs PC (1991). Anti-staphylococcal activity of temafloxacin, ciprofloxacin, ofloxacin and enoxacin. J. Antmicrob. Chemother. 28: 695-699.

Beatty JD, Beatty BG, Vlahos WG (1983). Measurement of monoclonal antibody affinity by non-competitive enzyme immunoassay. $\mathrm{J}$. Immunol. Methods, 100(1-2): 173-179.

Duan JH, Yuan ZH (2001). Development of an Indirect Competitive ELISA for Ciprofloxacin residues in food animal edible tissues. J. Agric. Food Chem. 49: 1087-1089.

Hammer P, Heeschen W (1995). Antibody-capture immunoassay for the detection of enrofloxacin. Milchwissenschaft, 50: 513-514.

Hernandez M, Borrull F, Calul M (2000). Determination of quinolones in plasma samples by capillary electrophoresis using solid-phase extraction. J. Chromatogr. B. 742: 255-265.

Higgins PG, Fluit AC, Schmitz FJ (2004). Fluoroquinolones: structure and target sites. Curr. Drug Targets, 4: 181-190.

Margarita H, Carme A, Francesc B, Marta C (2002). Determination of ciprofloxacin, enrofloxacin and flumequine in pig plasma samples by capillary isotachophoresis-capillary zone electrophoresis. J. Chromatogr. B. 772: 163-172.

Nagarall BS, Seetharamappa J, Melwanki MB (2002). Sensitive spectrophotometric methods for the determination of amoxycillin, ciprofloxacin and piroxicam in pure and pharmaceutical formulations. J. Pharmaceut. Biomed. 29: 859-864.

Nuria PN, Ester GI, Angel M, Rosa P (2007). Development of a groupspecific immunoassay for sulfonamides Application to bee honey analysis. Talanta, 71: 923-933.

Ramos M, Aranda A, Garcia E, Reuvers T, Hoohuis H (2003). Simple and sensitive determination of five quinolones in food by liquid chromatography with fluorescence detection. J. Chromatogr. B. 789: 373-381.
Raybould TJG, Inouye LK (1992). A monoclonal antibody-based immunoassay for detecting tetrodotoxin in biological samples. J. Clin. Lab. Anal. 6(2): 65-72.

Robert NH (1996). Chloramphenicol-specific antibody. Sci. Translational Med. 152: 203-205.

Ross CB, Larry HS (2001). An antigen based on molecular modeling resulted in the development of a monoclonal antibody-based immunoassay for the coccidiostat nicarbazin. Analytica Chimica Acta. 444: 61-67.

Singh KV, Kaur J, Varshney GC, Raje M, Suri CR (2004). Synthesis and Characterization of Hapten-Protein Conjugates for Antibody Production against Small Molecules. Bioconjugate Chem. 15: 168173.

Steffensa GC, Nothdurfta L, Buse G, Thissen H, Hocker H, Klee D (2002). High density binding of proteins and peptides to poly(D,Llactide) grafted with polyacrylic acid. Biomaterials, 23: 3523-3531.

Van Caekenberghe DL, Pattyn SR (1984). In vitro activity of ciprofloxacin compared with those of other new fluorinated piperazinylsubstituted quinoline derivatives. Antimicrob. Agents. Ch. 25: $518-521$

Veiopoulou CJ, loannou PC, Lianidou ES (1997). Application of terbium sensitized fluorescence for the determination of fluoroquinolone antibiotics pefloxacin, ciprofloxacin and norfloxacin in serum. J. Pharmaceut. Biomed. 15: 1839-1844.

Wang ZH, Zhu Y, Ding SY (2007) Development of a monoclonal antibody -based broad-specificity ELISA for fluoroquinolone antibiotics in foods and molecular modeling studies of cross-reactive compounds. Anal. Chem. 79: 4471-4483.

Watanabe H, Satake A, Kido Y, Tsuji A (2002). Monoclonal-based ELISA and immuno-chromatographic assay for enrofloxacin in biological matrices. Analyst. 127: 98-103

Yang IG, Hu SY, Wei PH (1998). Enzyme immunoassaytechnic[M], Nanjing University Publishing Company. pp. 279-281.

Zhou XJ, Chen CX, Yue L, Sun YX, Ding HZ, Liu YH (2008). Excretion of enrofloxacin in pigs and its effect on ecological environment. Environ. Toxicol. Pharm. 26: 272-277. 